\title{
ANALISIS ASPEK KUALITAS KEBERTERIMAAN FRASA NOMINA DALAM MAJALAH “COLOURS” GARUDA INDONESIA DARI BAHASA INGGRIS KE BAHASA INDONESIA
}

\author{
Yoyok S. Waluyo ${ }^{1,}$, , Laelah Fauziah $^{2}$ \\ Jurusan Teknik Informatika Dan Komputer Penerjemah Bahasa Inggris \\ Politeknik Negeri Jakarta \\ e-mail : ${ }^{1}$ yoyok.sw@tik.pnj.ac.id, ${ }^{2}$ laelahfau@gmail.com
}

\begin{abstract}
This study is a translation study focused on translation technique and quality especially on acceptability aspect. Linguistic units used to analyze is noun phrases existed in the magazine of "Colours Garuda Indonesia" published on November 2018. This study uses a qualitative descriptive method. Translation technique used refers to Molina\&Albir and translation quality assessment uses categories proposed by Nababan, et.als. The study reveals that types of noun phrases mostly found in this study are modification noun phrases. The most commonly translated using established equivalence. The quality aspect of acceptability translation is on the score 2.7 of 3 . It means result of translation can be accepted well by the reader of Bahasa Indonesia. Words or phrases translated reader comprehend them well because they are usually used in Bahasa Indonesia.
\end{abstract}

Key words : types of noun phrases, translation techniques, aspects of translation quality, acceptability

\begin{abstract}
ABSTRAK
Penelitian ini merupakan penelitian bidang penerjemahan berfokus pada teknik penerjemahan dan kualitas terjemahan yang khususnya di aspek keberterimaan. Unsur linguistik yang menjadi fokus terjemahannya adalah berupa jenis-jenis frasa nomina dalam majalah "Colours Garuda Indonesia" edisi November 2018. Penelitian ini merupakan penelitian dengan metode kualitatif deskriptif. Teknik penerjemahan mengacu pada jenis yang diusulkan oleh Molina\&Albir, dan kualitas terjemahan mengacu pada model yang diajukan oleh Nababan, et.als. Penelitian menunjukkan bahwa jenis frasa nomina yang banyak ditemukan dalam penelitian ini adalah frasa nomina modifikatif. Teknik penerjemahan yang banyak digunakan adalah padanan lazim. Kualitas terjemahan keberterimaan diperoleh nilai 2.7 dari nilai tertingginya 3. Artinya bahwa kualitas terjemahan yang dihasilkan memiliki kualitas berterima. Pembaca mampu menangkap hasil terjemahan dengan baik karena kata atau istilah yang diterjemahkan sudah lazim dan terbiasa dipahami.
\end{abstract}

Katakunci : frasa nomina, teknik penerjemahan, aspek kualitas terjemahan, keberterimaan

\section{PENDAHULUAN}

Majalah merupakan media publikasi yang berisi cerita pendek, gambar, review, promosi atau ilustrasi yang dapat mewarnai isi dari majalah agar majalah tersebut menarik untuk dibaca.

Penerjemahan berkaitan dengan tata bahasa, adanya perbedaan dalam tata bahasa seorang penerjemah harus berusaha mencari padanan yang paling dekat pada teks sasaran (BSa) untuk mengungkapkan makna suatu kata, frasa, klausa atau kalimat dari teks sumber (BSu) yang tentunya bisa diterima oleh para pembaca.

a) Aarts dan Aarts (1982: 110-11) menyebutkan bahwa frasa nomina adalah dua kata atau lebih yang berfungsi sebagai subjek, objek, atau objek preposisi dalam sebuah kalimat.

b) Menurut Nababan (2012:44) parameter suatu terjemahan yang berkualitas diukur dari tiga aspek, yaitu aspek keakuratan, keberterimaan dan keterbacaan. 
Aspek keberterimaan dalam terjemahan yang berkualitas merupakan sebuah istilah yang digunakan dalam mengevaluasi terjemahan untuk merujuk pada apakah BSu dan BSa sudah sepadan ataukah belum sepadan (Nababan\&dkk 2012: 44).

\section{Perumusan Masalah}

Berdasarkan uraian latar belakang di atas maka permasalahan yang dapat ditemukan adalah sebagai berikut:

1. Jenis frasa nomina apa saja yang terdapat dalam majalah Colours Garuda Indonesia?

2. Teknik penerjemahan apa saja yang digunakan pada majalah Colours Garuda Indonesia?

3. Bagaimana aspek kualitas terjemahan yang ada dalam majalah Colurs Garuda Indonesia dalam memenuhi aspek keberterimaan dalam penilaian kualitas suatu terjemahan?

\section{Tujuan Penelitian}

Berdasarkan perumusan masalah, terdapat tujuan penelitian adalah sebagai berikut:

1. Mengklasifikasi jenis-jenis frasa nomina dalam majalah Colours Garuda Indonesia.

2. Menentukan teknik penerjemahan yang digunakan dalam majalah Colours Garuda Indonesia berbahasa Inggris ke dalam bahasa Indonesia.

3. Menentukan tingkat keberterimaan dalam terjemahan majalah Colours Garuda Indonesia terhadap kualitas suatu terjemahan.

\section{Tujuan Penelitian}

1. Manfaat Teoritis

Penelitian ini diharapkan dapat memberikan manfaat bagi perkembangan dalam ilmu terjemahan, terutama pada jenis frasa nomina dan bahasa Inggris, serta mengetahui teknik penerjemahan dalam suatu terjemahan dan mengetahui aspek kualitas keberterimaan terjemahan frasa nomina ke dalam bahasa Indonesia.

2. Manfaat Praktis

a. Penelitian ini diharapkan dapat menambah wawasan kepada pembaca terutama pada teknik penerjemahan dan aspek kualitas keberterimaan dalam terjemahan frasa nomina.

b. Penelitian ini diharapkan dapat menjadi referensi terhadap penelitian selanjutnya mengenai terjemahan frasa nomina pada majalah.

\section{Batasan Penelitian}

1. Penelitian ini hanya membahas penerjemahan data yang termasuk ke dalam jenis frasa nomina yang terdapat dalam majalah Colours Garuda Indonesia .

2. Penelitian ini hanya membahas teknik penerjemahan yang digunakan dalam terjemahan majalah Colours Garuda Indonesia.

3. Penelitian ini hanya membahas aspek kualitas keberterimaan dalam terjemah majalah Colours Garuda Indonesia.

\section{Majalah Colours Garuda Indonesia}

Majalah Colours Garuda Indonesia, merupakan majalah milik Garuda Indonesia yang bertujuan sebagai media promosi yang targetnya adalah penumpang pesawat Garuda Indonesia itu sendiri. Tidak hanya sebagai media promosi, tetapi juga sebagai media informasi yang sangat penting yang bisa 
kita dapatkan setelah membaca majalah tersebut. Majalah Garuda Indonesia memiliki 2 bahasa, yaitu bahasa Indonesioa dan bahasa Inggris.

\section{Tinjauan Pustaka}

\section{Pengertian Frasa}

Kridalaksana mengatakan bahwa frasa adalah "gabungan dua kata atau lebih sifatnya tidak predikatif” (Usman, 2015). Namun, predikatif di sini bukan berperan sebagai sebuah predikat.

Jenis Frasa Nomina

Frasa nomina dapat dibedakan menjadi

3 jenis yaitu :

1. Frasa Nomina Modifikatif adalah kelompok kata benda yang memberikan batasan pada penjelasan kata benda.

2. Frasa nomina koordinatif adalah kelompok kata benda yang memiliki kedudukan setara sebagai inti dalam kalimatnya, namun tidak saling menerangkan.

3. Frasa Nomina Apositif adalah kelompok kata benda yang memberikan keterangan lebih rinci atau detail untuk menjelaskan kata yang diikutinya dalam kalimat tersebut.

Unsur Pembentuk Frasa Nomina

1. Hulu (head) merupakan unsur utama pada sebuah frasa.

2. Modifikator (Modifier) menjelaskan bahwa modifikator atau modifier adalah unsur yang membatasi, memperluas atau menyifatkan induk frasa.

3. Pre-Modifier menjelaskan bahwa, "premodification, which comprises all the modifying or describing constituents before the head, other than the determiners".

4. Post-Modifier adalah modifikator yang diletakkan setelah induk frasa (head).

5. Determinator adalah kelompok kata dari kata yang yang memperkenalkan kata benda.

\section{Pengertian Penerjemahan}

Newmark membagi dua jenis penerjemahan, yakni penerjemahan semantic dan komunikatif (Waluyo, 2018). Ini menjelaskan bahwa secara umum, penerjemahan adalah pengalihan pesan dan ide dari bahasa sumber ke bahasa sasaran, tidak peduli apakah dalam bentuk tulisan atau bukan tulisan, sudah memiliki sistem tulisan atau belum, atau apakah salah satu atau kedua bahasa tersebut berbentuk bahasa isyarat. Sehingga dapat diambil pengertian bahwa penerjemahan adalah mengalihkan pesan atau ide yang ada dalam bahasa sumber dan tidak peduli jika penulisan baik atau tidak yang terpenting adalah pesannya tersampaikan, tetapi penulisan juga dapat memengaruhi baik atau tidaknya hasil penerjemahan tersebut bahkan pesannya tidak sempurna tersampaikan kepada pembaca.

\section{Teknik Penerjemahan}

Molina dan Hurtado Albir (2002) menyusun teknik penerjemahan diantaranya

Adaptasi (Adaptation), Peminjaman (Borrowing), Kalke (Calque), Kompensasi (Compensation), Deskripsi (Description), Kreasi Diskursif (Discursive Creation), Padanan Lazim (Established Equivalence), Amplifikasi Linguistik (Linguistics Amplification), Kompresi Linguistik (Linguistics Compression), Penerjemahan Harfiah (Literal Translation), Modulasi (Modulation), Partikularisasi (Particularization), Reduksi (Reduction), Substitusi (Substitution), Transposisi (Transposition), Variasi (Variation).

\section{Penilaian Kualitas Terjemahan Keberterimaan}

Keberterimaan merujuk pada apakah suatu terjemahan sudah diungkapkan sesuai dengan kaidah-kaidah, norma 
dan budaya yang berlaku dalam bahasa sasaran ataukah belum, baik pada tataran mikro.

\section{METODOLOGI PENELITIAN}

\section{Jenis Penelitian}

Penelitian ini termasuk jenis penelitian deskriptif kualitatif. Santosa (2017) menyatakan bahwa penelitian deskriptif kualitatif memiliki karakteristik yaitu data yang dikumpulkan berupa kata, kalimat, gambar yang sesuai dengan apa adanya pada saat penelitian dilakukan. Fokus data penelitian ini adalah jenis frasa nomina yang bersumber pada majalah Colours Garuda Indonesia.

\section{Teknik Pengumpulan Data}

Teknik pengumpulan data yang digunakan dalam penelitian ini adalah mengkaji dokumen dan arsip (content analysis) dan kuesioner. Kuesioner yang disediakan oleh penulis terdiri dari 130 data, yang dapat dilihat pada lampiran 3. Dari 130 data frasa nomina tersebut termasuk ke dalam 3 jenis frasa nomina, yaitu frasa nomina modifikatif, frasa nomina koordinatif dan frasa nomina apositif. Data 130 itu ditentukan teknik terjemahan yang digunakan dalam setiap kalimatnya dan menentukan penilaian dari aspek terjemahan keberterimaan.

\section{Teknik Analisis Data}

1) Analisis domain, peneliti mengidentifikasikan jenis-jenis frasa nomina yang terdapat dalam majalah Colours Garuda Indonesia.

2) Analisis taksonomi, peneliti mengklasifikasikan semua data ke dalam teknik penerjemahan yang ditemukan dalam data jenis-jenis frasa nomina.

3) Analisis komponensial, mengklasifikasikan semua data yang telah terkumpul dalam kategori jenisjenis frasa nomina teknik penerjemahan serta aspek keberterimaan pada hasil terjemahan yang ada dalam majalah Garuda Indonesia.

4) Analisis tema budaya, Pada analisis tema budaya akan didapat setelah dilakukan analisis terhadap domain, sehingga diperoleh simpulan akhir mengenai jenis frasa nomina apa saja yang ditemukan, teknik penerjemahan apa saja yang digunakan dalam proses penerjemahan dan bagaimana kualitas aspek keberterimaan terjemahan dari data frasa nomina yang diambil dari sumber data yaitu majalah Colours Garuda Indonesia edisi November 2018.

\section{HASIL dan PEMBAHASAN}

Jenis Frasa Nomina

\begin{tabular}{ccc}
\hline $\begin{array}{c}\text { Jenis Frasa } \\
\text { Nomina }\end{array}$ & Jumlah & Presentase \\
& & \\
\hline Modifikatif & 98 & $75 \%$ \\
Koordinatif & 5 & $4 \%$ \\
Apositif & 27 & $21 \%$ \\
Total & 130 & $100 \%$ \\
\hline
\end{tabular}

Jenis frasa nomima modifikatif lebih banyak ditemukan dari jenis frasa nomina lainnya, karena data dalam majalah banyak terdapat kata benda yang memberikan batasan pada penjelasan kata benda lainnya. Contoh Modifikatif: sophisticated camera diterjemahan menjadi kamera canggih, camera sebagai inti kalimat dan canggih sebagai pelengkap. Contoh Koordinatif: married couple, diterjemahnkan menjadi suami istri, kata suami istri adalah kata yang keduanya memiliki kedudukan sebagai inti dari kalimat tersebut. Contoh Apositif: seven layers, diterjemahkan menjadi tujuh lapisan, kata tersebut berperan sebagai pengganti unsur inti dari kalimat.

\section{Teknik Penerjemahan}

\begin{tabular}{ccc}
\hline $\begin{array}{c}\text { Teknik } \\
\text { Penerjemahan }\end{array}$ & Jumlah & Persentase \\
\hline Padanan Lazim & 69 & $39 \%$ \\
Peminjaman Murni & 31 & $17 \%$ \\
Modulasi & 19 & $10 \%$ \\
\hline
\end{tabular}


Berdasarkan tabel di atas, teknik penerjemahan yang banyak digunakan adalah teknik terjemahan padanan lazim karena dalam terjemahan ini banyak yang memggunakan padanan yang sering digunakan dalam bahasa seharihari.

\section{Aspek Keberterimaan}

\begin{tabular}{ccc}
\hline Kategori & Jumlah Data & $\%$ \\
Terjemahan & & \\
\hline Berterima & 101 & $78 \%$ \\
Kurang Berterima & 21 & $16 \%$ \\
Tidak Berterima & 8 & $6 \%$ \\
Total & 130 & $100 \%$ \\
Rata-rata & $(101 \times 3)+$ & 2.7 \\
& $(21 \times 2)+(2 \times 1)$ & \\
& $:$ & \\
\hline
\end{tabular}

Berdasarkan hasil pengolahan kuesioner ditemukan rata-rata keberterimaan terjemahan frasa nomina dalam data yang diambil dari majalah colours Garuda Indonesia adalah 2.7. nilai ini menunjukan bahwa sebagian besar terjemahan frasa nomina dalam majalah colours Garuda Indonesia sudah diterjemahkan secara berterima ke dalam bahasa Indonesia. Tetapi masih terdapat kalimat yang hilang ketika diterjemahkan ke dalam bahasa Indonesia, sehingga makna dalam majalah tersebut tidak tersampaikan dengan baik.

\section{KESIMPULAN DAN SARAN}

\section{Kesimpulan}

Penelitian ini jenis frasa nomina yang banyak ditemukan adalah frasa nomina modifikatif yang berjumlah 98 data dari 130 data keseluruhan. Teknik penerjemahan dalam Majalah Garuda Indonesia adalah teknik padanan lazim, dengan 69 data. Kualitas keberterimaan dalam terjemahan frasa nomina yang terdapat dalam majalah Colours Garuda Indonesia memiliki nilai rata-rata 2.7 dari nilai tertinggi 3 . Tingkat keberterimaan dengan nilai tersebut berarti pada kategori tinggi. Yang berarti hasil terjemahan dalam aspek keberterimaan ini diterima dengan baik oleh pembaca bahasa target. Istilah dan kata sudah lazim ditemukan dan dipahami dengan baik.

\section{Saran}

Penelitian selanjutnya dapat dilakukan dengan melihat pada aspek lainnya, yaitu keakuratan dan keterbacaan. Sementara unsur linguistic nya pun dapat diteliti kualitas terjemahan untuk jenis kata atau frasa lainnya. Karena majalah ini merupakan bagian dari upaya promosi, sehingga dapat dilakukan penelitian pengaruh dari kata atau frasa terhadap tujuan yang ingin dicapai oleh Garuda Indonesia.

\section{DAFTAR PUSTAKA}

[1] Aarts, F. and Aarts, J. 1982. English Syntatic Structure. London : Oxford Pergamon Press.

[2] Aswarina, F. 2015. An Analysis Of Noun Phrase In PERCY JAKSON AND THE SEA OF MONSTER NOVEL BY RICK RIORDAN. Palangkaraya: State Islamic Institude

[3] Catford, J. (1965). A Linguistic Theory of Translation: An Essay in Applied Linguistics. Oxford: Oxford University Press.

[4] Hoed, B. (2006). Penerjemahan dan Kebudayaan . Jakarta: Pustaka Jaya.

[5] Larson, Mildred L. 1984. Meaningbased Translation : A Guide to Cross. Language Equivalence. New York : univ. Press.

[6] Molina, L, \&. A. (2002). Translation Techniques Revisited: A Dynamix and Functionalist Approach. Barcelona: Erudit.

[7] Murdiyanti, N. 2014. Kajian Frasa Nomina Beratribut Pada Teks Terjemahan Al Quran Surat AlHazab. Surakarta: Universitas Muhammdiyah Surakarta. 
[8] Nababan, M., Nuraeni, A., \&. S. (2012). Kajian Linguistik dan Sastra. Pengembangan Model Penilaian Kualitas Terjemahan, Vol. 24.

[9] Newmark, P. 1988. A Text Book Of Translation. London: Prentice Hall.

[10] Santosa, R. (2017). Metode Penelitian Kualitatif Kebahasaan. Surakarta.

[11] Sutopo, H. (2006). Penelitian Kualitatif: Dasar Teori dan Terapannya dalam Penelitian. Surakarta: Universitas Sebelas Maret.

[12] Usman, R. 2015. Frase Nomina Dalam Artikel BEYOND FILM: EXPLORING THE CONTENT OF MOVIE OLEH JOHN SCACCO. Manado: Universitas Sam Ratulangi

[13] Waluyo, Y. S., Nababan, M., Santosa, R., \& Djatmika. (2018). Translation Quality of Expressive Speech Acts: An Implementation of Bald on Record Impoliteness in the Translation Novel "The Silkworm”. Advances in Social Science, Education and Humanities Research. 166, pp. 540 - 546. Solo: Atlantis Press.

[14] Verhaar, J. (2006). Asas-Asas Linguistik Umum. Yogyakarta: Gadjah Mada University Press. 